\title{
Public Private Participation for Infrastructure in Developing Countries
}

\author{
Dr. S. A. Adeyinka \\ Department of Urban and Regional Planning, Obafemi Awolowo University, Ile-Ife, Nigeria \\ (adeyinkasa@yahoo.co.uk) \\ Mr. O. B. Olugbamila \\ Department of Urban and Regional Planning, Obafemi Awolowo University, Ile-Ife, Nigeria \\ (benmotayo@yahoo.com)
}

\section{Doi:10.5901/ajis.2015.v4n2p11}

\section{Abstract}

\begin{abstract}
Of recent, significant development in the use of public private partnership in providing infrastructural facilities has become a new policy initiative in many countries, Nigeria inclusive. This became necessary in view of the inadequacy of existing infrastructures to cope with the demands of the urban dwellers due to the inability of the government at various levels to provide and maintain urban infrastructures which are essential ingredients of economic development of the nation. Apart from the acute shortages of these infrastructures, the available ones are witnessing a reverse revolutionary trend from the situation of inadequacies to that of dearth or outright decay. This paper therefore focuses on the state of infrastructural facilities in Nigeria, with a view to providing a framework that will ensure their provision and sustainability. The paper went on to trace the historical antecedent of infrastructure development and provision in Nigeria and the current efforts of government through the application of public private partnership (PPP) in infrastructural facilities provision. Factors militating against the provision and maintenance of these infrastructures were identified. The paper concluded that policy measures should be put in place by the government in form of appropriate legislation and regulations that will create a conducive environment for private operators and other stakeholders to ensure effective and efficient partnerships that will promote the provision of urban infrastructure.
\end{abstract}

Keywords: Infrastructural Facilities, Nigeria, Physical Planning, Partnership and Development.

\section{Introduction}

The provision of modern infrastructural facilities dates back to the period of the British colonial administration in the country. Although the aim of British colonial rule in Nigeria was economic, the authorities soon realized that in order to facilitate the commercial and other economic activities of interest to them, there should be some form of welfare planning. Consequently, apart from the development of various means of transport, which received the first priority early in the period of colonial administration, efforts were made in association with voluntary agencies to provide some other public services such as education, health care, electricity and water supply.

The term infrastructure can assume several meanings while some social scientist define the term to include such facilities as transport, communication and energy, others define it as also embracing water supply, health, education as well as town and country planning. Ayodele (1996) suggests that there are both economic and social dimensions to the term; the social infrastructure sub-sector covers social services such as education, health services, information and town and country planning. The economic infrastructure covers the hardcore economic activities which relates to the provision of electricity supply, water supply, gas supply, sewerage, storm water drainage and telephone services which are referred to as utilities (Enimola 2010). Thus the term infrastructure covers both social services and utilities.

In this regard, infrastructure refers to those facilities and services that provide the backbone for the development of other sectors of the economy. Its role as an important agent of development cannot be overemphasized and in this regard, Olayioye (2002), argued that infrastructure is a powerful tool influencing the rate and direction and type of land development.

Infrastructure has been described as the "wheels of economic activity" (World Bank, 1994). Thus, the provision of infrastructural facilities can deliver major benefits in economic growth, lead to poverty reduction among the populace, and environmental sustainability, but only when the services provided responds to demand and do so effectively.

The provision of infrastructural facilities is very crucial in the development of a nation. The manner in which 
provision of these basic infrastructural facilities are dispensed to meet the demands of the public in general will determine the level of economic activity and, in turn, the overall development of a nation. Most sectors cannot function without electricity, telecommunications and water; therefore, the adequate and effective provision of these services is central to the growth of an economy and the improvement of public welfare (UNESCO, 2005). Infrastructural facilities provide the basic environment for the production as well as the distribution of goods and services. It is a necessary ingredient for the effective growth and functioning of towns and cities and for the national promotion of social and physical development activities (Olugbamila, 2008).

Despite the importance of infrastructural facilities to the development and sustainability of our cities, and the significant attention paid to the provision of these facilities over the years by various administrations in the country, experience indicates that Nigeria is faced with the problem of inadequacy and poor management of public services. Of major importance is the fact that despite the efforts made by government in the provision of basic utilities and services in urban centres, the problem of inadequate and inefficient infrastructural facilities still persists.

This situation might not be unconnected with the rapid urbanization witnessed in Nigeria in the last four decades as a result of the oil boom era that occurred between 1971 and 1977. For instance in 1971, the share of agriculture to GDP stood at 48.23 per cent. By 1977, it had declined to almost 21 per cent. Agricultural exports, as a percentage of total exports, which was 20.1 per cent in 1971, reduced to 5.71 per cent in 1977 (www.tribune.com). The economy became heavily dependent on oil. By this time, oil revenue represented almost 90 per cent of foreign exchange earnings and about 85 per cent of total exports. While the boom afforded government much needed revenue, it also created serious structural problems in the economy (Ibid).

In consequence, rural-urban migration of unprecedented dimension emerged as many people attempted to benefit from the oil boom for their economic prosperity. According to the World Bank, the share of Nigeria's urban population rose from 20 percent in 1970, to 40 percent in 1993 (Zubairu, 1998). In 1963, the official census figure put the population of Nigeria as 55.6 million inhabitants. In 1973, it was estimated to be 79.7 million; in 1983, 90 million, and in 1986, close to 106 million (Taylor, 1988). In its last official census in 2006, the country's population was about 140 million with the metropolitan Lagos being a mega-city i.e. cities with 10 million population and above while it is projected that by the year 2020 cities like Kano, Ibadan and Port Harcourt would have joined the rank.

With this growing urban population, is the challenges posed by inadequacy of urban infrastructures which require huge government finances to meet their demand. Coupled with this problem is the economic downturn and hyper-inflation ravaging the country thereby making almost impossible for governments at the three levels to source for the needed fund to provide new infrastructural facilities or maintain the existing ones. Therefore, this has put a great pressure on these infrastructures and hence, they become terrible inadequate. Such problems of infrastructure deficiency manifest in form of housing shortage, inadequate urban water supply, poor and ill-maintained urban road network, erratic/epileptic electricity supply, poor communication and sewerage system, dysfunctional health and educational facility. It has become evident therefore, that government alone cannot muster the resources to meet these needs. Hence, successive government has evolved various policy approaches to these problems. According to Taiwo and Adegun (2011), a notable feature in the recent past in terms of delivery mechanism is Public-Private-Partnerships (PPP) which originally entails the provision of public assets and services through collaboration between government and private sector. According to them, the application of PPP in various sectors of the economy is becoming increasingly popular in Nigeria as well as other developing economies.

Against this background, this paper examines the principles, structure and attributes of PPP and suggested some viable recommendations that could ensure effective usage of the PPP for sustainable infrastructure provision in Nigeria urban centres.

\subsection{Physical Planning and Infrastructure}

Planning according to Olujimi (2011) is concerned with deliberately achieving some objectives (which may be individual or corporate) and it proceeds by evolving strategies and actions arranged in a prioritized order or sequence.

In view of this observation, planning involves thinking ahead and making advance arrangements to achieve particular objectives. Planning embraces the simple process of determining appropriate future action through a sequence of choice. Planning then becomes an idea that transcends the entire human endeavour. It can be applied to virtually all human activities, right from the level of individual, the family or neighbourhood to that of the town, district or society, and equally to the provision and management of infrastructural facilities.

Incorporating infrastructure into the definition of physical planning, Oyesiku, (2002) defined physical planning as an 
orderly spatial arrangement of the various land uses such as residential, commercial, industrial, recreation and open spaces, transportation, public infrastructure and other ancillary human activities. It is concerned with functional relationship among the various land uses with a view to ensuring that services are available and accessible to all conveniently and efficiently.

Physical planning aimed at providing a pleasant healthy physical environment for living, working, recreation and movement. In this regard, physical planning covers all aspects of human endeavour and all aspects of natural or manmade resources and yet performs a coordinating role to ensure harmony in the development and sustainability of our cities (Olujimi, 2010).

\section{State of Nigeria Infrastructure (Selected Cases)}

Nigeria today is largely a monolithic economy that can hardly survive any economic misfortune that may befall the leading economic sector (oil industry). This is made so as a result of the weak infrastructural development which ought to have provided the basic energy needed in sustaining a more diversified economy. More importantly, one would have thought that by the turn of the last $20^{\text {th }}$ century, what would have remain of infrastructure issues would merely be extension, expansion and the automation of the existing utility lines to accommodate both the needs of every individual and that of the corporate bodies on whose expertise the virility and sustainability of any nation largely depends.

Virtually all aspect of Nigeria's infrastructure is in deplorable condition. The power sector for instance is marked by low generating capacity relative to installed capacity. At present electricity generation ranges from between 2500 megawatts to about 3,000, even with the inclusion of three gas-powered independent power projects in the Niger delta region, while estimated national consumption is in excess of 10,000 megawatts. Potential demand in the next few (say three) years is estimated at about 15,000 megawatts (Oluba, 2008). Despite the fact that Nigeria is endowed with massive reserves of hydro energy, petroleum reserves and one of the largest gas reserves, electricity supply is still epileptic.

Transportation is an essential part of human activity, and in many ways form the basis of all socio-economic interactions. Indeed, no two locations will interact effectively without a viable means of movement. In many developing countries, Nigeria inclusive, inadequate transport facilities are often the norm rather than the exception. Thus, a good transport system is essential to support economic growth and development. Since the attainment of independence in 1960, the problems of Nigerian transport system include bad roads; inadequate fleets of buses or trucks; irregular, inadequate and overcrowded trains and airplanes and congested ports. These are common features of the developing world. In line with these are physical problems such as dearth of suitably-trained transport managers and planners, capital restructuring bottlenecks, serious issues of institutional reforms and ineffective traffic regulations. The share of transport in the Gross Domestic Product [GDP] is in the neighbourhood of 3 per cent (Oluba, 2008).

The length of roads in Nigeria is about 195,200 kilometres out of which about $15.3 \%$ is paved. About $28 \%$ of these paved roads are bad and not motorable which ultimately tends to retard the economy of the country (Oluba, 2008).

The railway infrastructure has suffered a dilapidated and deplorable condition. It is virtually moribund before the recent upgrading and rehabilitation. Well over 3,000km (90\%) of the entire existing Normal Gauge Lines throughout the federation is witnessing rehabilitation

Water is crucial to development but in Nigeria the agencies responsible for water service delivery in both urban and semi-urban areas have failed in the discharge of their duties. Nigeria is estimated to have $267.3 \times 10^{7}$ cubic metres of surface water and $51.9 \times 10^{9}$ cubic metres of groundwater (Nnabugwu, 2005). The country is currently experiencing a dwindling of her water resources. The main problem is that of development and management rather than that of water availability. The Nigerian water sector, according to Olugbamila (2008) is faced with the problems of lack of trained manpower/inappropriate technology, insufficient fund as well as lack of legal framework among others. Moreover, water is perceived as government responsibility for both rural and urban areas and at present, about 40 percent of Nigeria's population has access to safe water.

Nigeria's infrastructure challenge is huge. Recent reports suggest that the country requires between US $\$ 12$ billion to $\$ 15$ billion annually for the next six years to meet the infrastructure requirements (Izuwah, 2010).

On a more general note, Nigeria's infrastructure has almost crumbled. In many urban areas, water supply, sewerage, sanitation, drainage, roads, electricity, waste disposal are virtually non-existent. Maintenance of the partially existing ones is zero. All these are being compounded by the twin problems of rapid population growth and urbanization (Oluba, 2008). 


\section{Historical Antecedent of Infrastructure Development and Provision in Nigeria}

Infrastructural provision such as water, electricity and waste disposal facilities among others in Nigerian cities has for long time been recognized by various governments in the country. It has for long been appreciated that apart from the vital role which these facilities play in the economic life of the cities, they also play a crucial role in the maximization of social welfare of urban/city dwellers. For example, while electricity supply provides the main source for industrial and commercial development in Nigeria, it is also a social amenity for households who need it for the performance of basic household's activities. The provision of these not only facilitates economic activity but also provide important direct consumption benefits.

Before the amalgamation of the Northern and Southern protectorate and Lagos Colony in 1914, indigenous approaches via communal efforts were largely the means by which infrastructural facilities and social services were provided and sustained. In this way, essential infrastructures such as water, road network, and market remain the responsibility of the larger community. Thus the sustainability of any city or nation depends on the amount and the level of development of the available infrastructural facilities.

However, the advent of the colonialist usher in a new approach to infrastructure provision and maintenance, as selected areas whose economic viability had been ascertained were the target. Even the targeted settlements were discriminatorily provided for as selected areas within such settlement were highly favoured. This according to Omosulu (2002) translated into the creation of three different residential quarters in Ibadan. These quarters are the European quarters, the African quarters and the indigenous quarters or traditional settlement. These quarters' represent two different extremes and the mid way approach towards development. These are European on the extreme, the African at the middle and the indigenous settlements at the other extreme all of which had effects on the spatial development and distribution of infrastructural facilities across the nation. In other words, the pervasive imbalance infrastructural development across the nation is the aftermath of colonial ideology of isolationism. What becomes of the Nigeria nation today in terms of economic development and national sustainability is attributable to the insufficiency, inefficiency and ineffectiveness of the available infrastructural facilities which are concentrated in isolated urban areas like Lagos, Ibadan, Enugu, Port-Harcourt, Kaduna and Abuja. It was observed, though rightly, that a situation where about $25 \%$ of the total earnings accruing to the industrial sector is further invested in the provision and maintenance of infrastructures such as electricity, water supply, road network, drainage facilities which does not augur well for the economic well being and growth of the nation. This situation therefore calls for urgent and all-embracing approach that will ensure adequate provision of infrastructural facilities for the sustainability of Nigerian cities.

\section{New Initiatives/Approach in Infrastructure Development}

Lately, there has been a downward trend in the level of infrastructure development and management in Nigeria. The promotion of infrastructural development attained its peak in the decades that span through 1960s -1970s and 1970s 1980s. For instance, what remains of the European legacy after independence in 1960 was improved upon by the indigenous government of the first republic and the subsequent military government that came on board. At his period, development of infrastructural facilities attained unparalleled and unprecedented growth in the country. Since then, government has been under intensive pressure to explore alternative ways for infrastructure provision. The past few years, therefore, have witnessed an upsurge in the commercialization of public services provision through building partnerships with the private sector. In general, the rationale behind involving the private sector is to avoid the potential pitfalls of full privatization, utilize new technology and expertise, share risks and gain access to increased capital to improve operating efficiency, and, ultimately, private sector and civil society organization (CSO) roles have become more clearly defined and public-private partnership (PPP) schemes have become more popular.

\subsection{Public-Private Partnership (PPP)}

Public Private Partnerships are now commonly used to accelerate economic growth, development and infrastructure delivery and to achieve quality service delivery and good governance (Akintoye, 2015). PPP has been defined as a contractual arrangement which is formed between public and private sector partners which involves the private sector in the development, financing, ownership and or operation of a public facility or service (Ogunsanmi, 2014). According to Adirieje (2009), Public-Private Partnership or PPP relate to perceptions and practices affecting public private sector relationships in ensuring national/global health, development and wellbeing of the society, and the conceptual aspects of 
such relationships, including the role of the key players in collaborating to make these partnerships successful or otherwise. In addition, there has been tremendous development in the use of PPP in many countries that has made it increasingly important to understand these practices and given the changing economic, social and political environment, coupled with globalization and budgetary constraints, PPP has become unavoidable and indeed desirable in many countries worldwide.

PPP is collaboration between the public sector and the private sector, in which the private sector provides a public service or project and assumes substantial financial, technical and operational risk in the project. The main aim of the initiative is to bring private sector skills and finance into projects that would have previously been wholly or mainly provided by the public sector. This approach of developing and operating public utilities and infrastructure by the private sector under terms and conditions agreeable to both the government and the private sector is called PPP or P3 or Private Sector Participation (PSP).

The participants in a PPP, could be a private company, a consortium, or a governmental organization (NGO). The PPP project is an involvement between a public sector agency and a private sector consortium which comprises contractors, maintenance companies, private investors, and consulting firms.

\subsubsection{Types of public-private partnership}

- Service contract, this involves the government and the private sector where the rights and obligation to perform a specific service within a well defined specifications and period are awarded by the government to the private sector. Government continues to take possession of and control of all facilities, capital assets and properties.

- Management contract.

- Transferred to the private party who is generally not expected to invest in the facility.

- Lease, where the private party manager and operate an existing public facility and pays a specified lease payment to the government.

- Concessions, where the private sector have total control over the management and operation of the facilities, often on a long-term basis.

This may take the form of:

$>$ build-operate-transfer (BOT),

$>$ build- operate-own (BOO) or build-own-operate-transfer (BOOT),

$>$ rehabilitate, operate and transfer (ROT),

$>$ design-build-operate-transfer (DBOT),

$>$ design-build, finance and operate (DBFO),

$>$ build-operate-maintain (BOM).

$>$ build, rent/lease and transfer (BRT or BLT) and,

$>$ build transfer and operate (BTO).

- Private finance initiative (PFI), a concept where the private-sector funds a particular project and operates it for an agreed period.

\subsection{Public Private Partnership in Nigeria}

The lack of public capital; and/or a lack of public sector capacity, resources and specialized expertise to develop, manage, and operate infrastructure assets have led to the realization that private sector participation in the provision of infrastructure is inevitable.

The World Bank estimates that every $1 \%$ of (government) funds invested in infrastructure leads to an equivalent $1 \%$ increase in gross domestic product (GDP). Nigeria has not had a consistent history of investment in infrastructure; however, recent government agenda show that infrastructure development is gaining momentum. In the past 10 years, over 25 major infrastructure projects have been rolled out through PPPs. The Federal Government of Nigeria, State and Local Government Areas (LGAs) have contributed over N10 trillion (\$66 billion) to these. However, the total investment required to meet the vision 2020 target for infrastructure projects is N32 trillion (\$210 billion) (Izuwah, 2010)

The concept of public private partnership is not entirely novel to Nigeria. This necessitated the infrastructure summit of 2008, where the federal government noted that the physical infrastructure deficit cannot sustain the level of economic development which the government envisages. The government recognized that effectively tackling the 
infrastructure challenges would require multi-billion dollar investment, new policies and institutional reform. This is a challenge that calls for new approaches to the provision of infrastructure services through innovative financing mechanism (Infrastructure Summit, 2008). The government further stated that Nigeria has come to the conclusion that it is only through deliberate, structured policy choices that the country can realistically embark upon remedying the physical infrastructure challenge which is facing the country. This can be achieved through the Public Private Partnership (PPP) initiative.

Some elements of the PPP include the Independent Power Plant (IPP) arrangement with some private companies to generate power supply; the Lagos state government arrangement with some firms on waste collection and disposal; the federal government arrangement with Solgas to revive the Ajaokuta Steel plant; the federal government arrangement with Bi-Courtney Aviation Services Limited to develop and build the Muritala Mohammed Airport 2 (MMA 2), Ikeja, lagos; the recent award of the repair of the Lagos/lbadan expressway to Bi-Courtney Highway Services Limited on a DBOT basis, etc. However, it is expected that a formal framework that will ensure transparent and competitive bidding is put in place by the government.

The telecommunication story in Nigeria has changed with the introduction of the Global System of Mobile Communication (GSM). This involves the granting of operating licenses to GSM service providers. With this step alone more than $60 \%$ of Nigerians have access to GSM telephones. The private sector participation in telecommunication infrastructure has made communication effective and efficient in Nigeria.

\section{Policy Recommendation}

Development of a nation depends on the functionality of every sectors of the economy. When infrastructure functions efficiently, the whole society benefits and the resultant effects are manifested on the growth and development of the community. When it functions below expectation, everybody pays both in cash and kind, therefore to remedy the lukewarm attitude towards infrastructural facilities provision and maintenance, which has been a clog in the development of the nation, the following are recommended.

- Formulation of a clear legislation that will give guide the operation of the private sector participation and protect their financial interests and property right.

- A legal framework should be put in place to ensure policy continuity for private sector participation.

- Government should provide an enabling environment for the attraction and retention of the private sector's interest in infrastructural facilities development, provision and management.

- Education and enlightenment of the general public on the need and benefits of private financiers in the provision of infrastructural facilities.

- Setting up of monitoring agency for the control and evaluation of PPP projects

- Nigerian roads are bad and in a deplorable condition, ditto other infrastructural facilities, hence there is need to involve more private sector participants/investors to repair and maintain some if not all our roads and other infrastructural facilities. The recent award of the repair/maintenance Lagos/lbadan highway to Bi-Courtney Highway Services Limited on a design, build, operate and transfer (DBOT) basis is a step in the right direction.

- Private people or organizations should be given franchises to construct and maintain roads and take tolls on them. Ditto for other infrastructural facilities and services. Private infrastructure franchises that are properly designed and strictly policed hold the key for infrastructure provision.

\section{Conclusion}

The present state of infrastructure across the nation depicts gory spectacle which needs to undergo 'surgical operation'. Considering the important roles of good infrastructural facilities outlay in the promotion of a strong economic base for the nation, the present approach where their provision and maintenance is left in the hand of the government alone is no longer acceptable. It is suggested therefore that private initiatives in the provision and maintenance of infrastructural facilities be encouraged, and should be done within the framework of economic revitalization of the nation through public participation and privatization of infrastructure subsystem of the economy.

If and when the above is strictly adhered to, a strong base must have been laid for infrastructural provision and maintenance in Nigerian cities which in the long run will ensure sustainable growth and economic development. 


\section{References}

Aderieje, U.A (2009): Public-Private Partnership and Nigeria's Development, http://www.fpppn.org/pppnd_dr_uzodima.html. Assessed on March 2nd 2012.

Akintoye, A (2015): Public Private Partnership: Variation and Country Context. Keynote Address, Environmental Design and Management International Conference, Obafemi Awolowo University, Ile-Ife, Nigeria. (9 $9^{\text {th }}-12^{\text {th }}$ March 2015.

Ayodele, S. (1996): "Development and Management of Utilities in Nigeria". CASA Monograph No. 9, Malthouse press Limited, Lagos, Nigeria.

Enimola, S.S. (2010): "Infrastructural Economic Growth: the Nigeria Experience. 1980 - 2006". Journal of Infrastructure Development. www.m.referencerepository.com. Assessed on April $8^{\text {th }} 2015$

Infrastructure Summit (2008): President Yar'Adua's Address at Infrastructure Summit. http://www.nigeriafirst.org/printer_8354.shtml. Assessed on September 23rd 2011.

Izuwah C. (2010): 2nd National Project Management Conference, Abuja - September 2010

Nnabugwu, O. (2005): Weather, Climate, Water and Sustainable Development in Nigeria. Paper presented on the occasion of the 2005 World Metrological Day Celebration, held at the Metrological Conference Centre.

Ogunsanmi, O.E. (2014): Critical Success Factors (CSF) Determining the Implementation of Public-Private Partnership Projects. Covenant Journal of Research in the Built Environment (CJRBE) Vol. 1, No. 2. March, 2014.

Olayioye, J.T. (2002): "Sustainable Management of Urban Infrastructure: A Case Study of Potable Water Supply in Ilorin, Kwara State". Paper Presented at the $3^{\text {rd }}$ national Conference of the School of Business, Federal Polytechnic, Ede $10^{\text {th }}-13^{\text {th }}$ December.

Oluba, M. (2008): Who Should Provide Public Infrastructure in Nigeria? www.proshareng.com. Assessed on March 25th 2015

Olugbamila, O.B. (2008): "Assessing the Millennium Development Goals for Adequate Water

Supply in Owo, Ondo State" in Akinnowo E.O et al (ed) Socio-Economic Policies and Millennium Development Goals (MDGs) in Africa. Faculty of Social and Management Sciences, Adekunle Ajasin University, Akungba Akoko. Pp 329- 335.

Olujimi, J.A.B. (2010): The Administration of Physical Planning in Nigeria: the Ondo State Experience. www.researchgate.net/ publication/2223735

Olujimi, J.A.B. (2011): From Rural to Urban: The Nigerian Physical planning Dilemma. 63rd Inaugural Lecture. Federal University of Technology, Akure, Ondo State.

Omosulu, S.B. (2002): "Infrastructural Development and Management as an Essential Factor in Building a Virile Nation". Paper Presented at the $3^{\text {rd }}$ national Conference of the School of Business, Federal Polytechnic, Ede $10^{\text {th }}-13^{\text {th }}$ December.

Oyesiku, O.O (2002): From Womb to Tomb. 24th Inaugural Lecture, Olabisi Onabanjo University, Ago-Iwoye, Ogun State

Taiwo, A.A. and Adegun, O.B. (2011): Public-Private Partnership in Housing in Nigeria and the Case for Community Participation in Laryea, S. and Leiringer, R.(Eds) Proceedings of the West African Built Environment Research (WABER) 2011 Conference, Vol. 2

Taylor. R. W. (1988): Urban Development Policies in Nigeria: Planning, Housing, and Land Policy, Department of Environmental, Urban and Geographic Studies, Montclair State University, Upper Monclair, New Jersey

UNESCO (2005): Public-Private partnerships for Service Delivery: Water and Sanitation. Third Meeting of the Committee on Human Development and Civil Society, Addis Ababa, Ethiopia, 4-6 May, 2005.

World Bank (1994): World Development Report.

Zubairu, M. (1998): Urban Infrastructure Financing: Strategy and Options, A Paper Presented at the National Workshop on the Modalities of Implementation of the National Urban Development Policy for Nigeria held at Sheraton Hotels and Towers, Abuja, $13^{\text {th }}-16^{\text {th }}$ July. 
